\title{
Paenibacillus yonginensis sp. nov., a potential plant growth promoting bacterium isolated from humus soil of Yongin forest
}

\author{
Johan Sukweenadhi $\cdot$ Yeon-Ju Kim $\cdot$ Kwang Je Lee • \\ Sung-Cheol Koh • Van-An Hoang • Ngoc-Lan Nguyen • \\ Deok-Chun Yang
}

Received: 9 June 2014/Accepted: 14 August 2014/Published online: 29 August 2014

(C) Springer International Publishing Switzerland 2014

\begin{abstract}
Strain DCY84 ${ }^{\mathrm{T}}$, a Gram-stain positive, rodshaped, aerobic, spore-forming bacterium, motile by means of peritrichous flagella, was isolated from humus soil from Yongin forest in Gyeonggi province, South Korea. Strain DCY $84^{\mathrm{T}}$ shared the highest sequence similarity with Paenibacillus barengoltzii KACC $15270^{\mathrm{T}}(96.86 \%)$, followed by Paenibacillus timonensis KACC $11491^{\mathrm{T}}(96.49 \%)$ and Paenibacillus
\end{abstract}

Electronic supplementary material The online version of this article (doi:10.1007/s10482-014-0263-8) contains supplementary material, which is available to authorized users.

J. Sukweenadhi · Y.-J. Kim $(\bowtie)$ · K. J. Lee ·

V.-A. Hoang · N.-L. Nguyen · D.-C. Yang $(\bowtie)$

Korean Ginseng Center and Ginseng Genetic Resource

Bank, Kyung Hee University, Seocheon-dong, Giheunggu, Yongin-si 449-701, Gyeonggi-do, Republic of Korea e-mail: yeonjukim@khu.ac.kr

D.-C. Yang

e-mail: deokchunyang@yahoo.co.kr

J. Sukweenadhi

Faculty of Biotechnology, University of Surabaya

(UBAYA), Surabaya, Indonesia

S.-C. Koh

Department of Environmental Engineering, Korea

Maritime University, Busan, Republic of Korea phoenicis NBRC $106274^{\mathrm{T}}(95.77 \%)$. Strain DCY84 ${ }^{\mathrm{T}}$ was found to able to grow best in TSA at temperature $30{ }^{\circ} \mathrm{C}$, at $\mathrm{pH} 8$ and at $0.5 \% \mathrm{NaCl}$. MK-7 menaquinone was identified as the isoprenoid quinone. The major polar lipids were identified as phosphatidylethanolamine, an unidentified aminophospholipid, two unidentified aminolipids and an unidentified polar lipid. The peptidoglycan was found to contain the amino acids meso-diaminopimelic acid, alanine and D-glutamic acid. The major fatty acids of strain $\mathrm{DCY} 84^{\mathrm{T}}$ were identified as branched chain anteiso- $\mathrm{C}_{15: 0}$, saturated $\mathrm{C}_{16: 0}$ and branched chain anteiso- $\mathrm{C}_{17: 0}$. The cell wall sugars of strain DCY $84^{\mathrm{T}}$ were found to comprise of ribose, galactose and xylose. The major polyamine was identified as spermidine. The DNA G+C content was determined to be $62.6 \mathrm{~mol} \%$. After 6 days of incubation, strain $\mathrm{DCY} 84^{\mathrm{T}}$ produced $52.96 \pm 1.85$ and $72.83 \pm 2.86 \mu \mathrm{g} / \mathrm{ml} \quad$ L-indole-3-acetic acid, using media without L-tryptophan and supplemented with Ltryptophan, respectively. Strain DCY $84^{\mathrm{T}}$ was also found to be able to solubilize phosphate and produce siderophores. On the basis of the phenotypic characteristics, genotypic analysis and chemotaxonomic characteristics, strain DCY $84^{\mathrm{T}}$ is considered to represent a novel species of the genus Paenibacillus, for which the name Paenibacillus yonginensis sp. nov. is proposed. The type strain is DCY $84^{\mathrm{T}}\left(=\mathrm{KCTC} 33428^{\mathrm{T}}=\mathrm{JCM}\right.$ $19885^{\mathrm{T}}$ ).

Keywords Paenibacillus yonginensis · Gramstaining-positive $\cdot$ Plant growth promoting 


\section{Introduction}

Direct use of microorganisms to promote plant growth and to control plant pests continues to be an area of rapidly expanding research (Weller 2007). Those bacteria which can promote plant growth, called plant growth-promoting bacteria (PGPB), include either those which form specific symbiotic relationships with plants or those which are free-living or endophytic bacteria which can colonize plant tissues. The members of the genus Paenibacillus are well known as PGPB, together with Azotobacter, Azospirillum, Pseudomonas, Acetobacter and Burkholderia (Hayat et al. 2010). Many new species from the genus Paenibacillus have been reported, along with more research ongoing. The genus Paenibacillus was first proposed by Ash et al. (1991) and later its description was emended by Shida et al. (1997). Members of this genus are ubiquitous in nature and species have been isolated from various environments such as petroleum-hydrocarbon-contaminated sediment (Montes et al. 2004), warm springs (Saha et al. 2005), alkaline soils (Yoon et al. 2005), rice fields (Sánchez et al. 2005), a spacecraft assembly facility (Osman et al. 2006), ginseng field soil (Park et al. 2007), poultry litter compost (Vaz-Moreira et al. 2007), phyllosphere (Valverde et al. 2008), gut (Park et al. 2009), rhizosphere (Beneduzi et al. 2010), a subsurface molybdenum mine (Benardini et al. 2011), tidal flat (Wang et al. 2012), nodules (Carro et al. 2013) and gamma-irradiated Antarctic soil (Dsouza et al. 2014). At the time of writing, there are nearly 150 species of the genus Paenibacillus with validly published names (http://www.bacterio.net/paenibacillus.html). Members of the genus Paenibacillus are Gram-positive or Gram-variable, rod-shaped bacteria, and strictly aerobic or facultatively anaerobic (Ash et al. 1991). The major fatty acid is anteiso- $\mathrm{C}_{15: 0}$, the predominant isoprenoid quinone is unsaturated menaquinone with seven units (MK-7) and meso-diaminopimelic acid is commonly found in the peptidoglycan (Priest 2009). In this study, we characterized a new isolate, strain DCY $84^{\mathrm{T}}$, belonging to the genus Paenibacillus from humus soil from Yongin forest in Gyeonggi province, South Korea. The phenotypic and genotypic characterizations of the novel strain are described in this report and we propose that strain $\mathrm{DCY} 84^{\mathrm{T}}$ represents a novel species, for which the name Paenibacillus yonginensis sp. nov. is proposed.

\section{Materials and methods}

Isolation, morphological and physiological characterization

Samples from several random spots at Yongin forest were carefully collected in clean zip lock covers, without any stones or particles, and transferred to the laboratory. One gram of sample was dissolved in $10 \mathrm{ml}$ of $0.85 \%(\mathrm{w} / \mathrm{v})$ saline solution, serially diluted up to $10^{-5}$ and spread on 5 times diluted Reasoneŕs $2 \mathrm{~A}$ (R2A) agar (MB cell). The plates were incubated at $30^{\circ} \mathrm{C}$ for 3 days. Single colonies were purified by transferring them to new R2A agar plates. A novel Paenibacillus, designated as DCY $84^{\mathrm{T}}$, was isolated and characterized in this study. The isolate was routinely cultured on R2A agar at $30{ }^{\circ} \mathrm{C}$ and stored at $-80{ }^{\circ} \mathrm{C}$ as a suspension in R2A broth with $30 \%(\mathrm{v} / \mathrm{v})$ glycerol. However, later the media was changed to Trypticase Soya Agar (TSA, MB cell) and Trypticase Soya Broth (TSB) after checking results for optimum growth of this strain. Strain DCY $84^{\mathrm{T}}$ has been deposited in the Korean Collection for Type Cultures (as KCTC 33428 ${ }^{\mathrm{T}}$ ) and Japan Collection of Microorganisms (as JCM 19885 ${ }^{\mathrm{T}}$ ). Paenibacillus barengoltzii KACC $15270^{\mathrm{T}}$ and Paenibacillus timonensis KACC $11491^{\mathrm{T}}$ were obtained from the Korean Agricultural Culture Collection and Paenibacillus phoenicis NBRC $106274^{\mathrm{T}}$ was obtained from the National Institute of Technology and Evaluation (NITE) Biological Resource Center for use as reference type strains. These strains were cultured under the same optimum conditions as strain DCY $84^{\mathrm{T}}$.

Based on the proposed minimal standards for the description of aerobic, endospore-forming bacteria (Logan et al. 2009), standard tests were performed for phenotypic characterization of strain DCY $84^{\mathrm{T}}$. Strain DCY $84^{\mathrm{T}}$ colonies were observed after culturing on TSA agar plate at $30{ }^{\circ} \mathrm{C}$ after incubation for $48 \mathrm{~h}$. Gram-reaction was tested by using a bioMérieux Gram stain kit. Cells were grown in TSB for $24 \mathrm{~h}$ at $30^{\circ} \mathrm{C}$ and then tested for gliding motility by the hangingdrop technique (Skerman 1967). Cell morphology and flagella were detected by using transmission electron microscopy (Carl Zeiss LOE912AB). Suspended cells previously grown on TSA at $30{ }^{\circ} \mathrm{C}$ for $48 \mathrm{~h}$ were placed on carbon- and formvar-coated nickel grids for $30 \mathrm{~s}$ and grids were floated on one drop of $0.1 \%(\mathrm{w} / \mathrm{v})$ aqueous uranyl acetate, blotted dry and then viewed 
with a Carl Zeiss electron microscope (LOE912AB) at $100 \mathrm{kV}$ under standard operating conditions.

Different media were tested for growth such as R2A, TSA, Nutrient Agar (NA, MB cell), LuriaBertani (LB, MB cell) agar, Potato Dextrose Agar (PDA, MB cell) and MacConkey Agar (Difco) at $30{ }^{\circ} \mathrm{C}$ for 7 days. For checking growth at different temperature, a range of 4, 8, 15, 20, 25, 30, 37, 40 and $45{ }^{\circ} \mathrm{C}$ were tested for 7 days. The salinity test was checked by using $0.5-9.5 \%(\mathrm{w} / \mathrm{v}) \mathrm{NaCl}$ in TSB using increments of $1 \%$. Growth of strain $\mathrm{DCY} 84^{\mathrm{T}}$ was also checked at different $\mathrm{pH}$ values, from 4 to 10 in TSB using increments of $1 \mathrm{pH}$ units. The following buffers were used to adjust the $\mathrm{pH}$ values: citric acid/sodium citrate $(\mathrm{pH} \quad 4.0-6.0), \quad \mathrm{Na}_{2} \mathrm{HPO}_{4} / \mathrm{NaH}_{2} \mathrm{PO}_{4} \quad(\mathrm{pH}$ 6.0-8.0), $\mathrm{Na}_{2} \mathrm{CO}_{3} / \mathrm{NaHCO}_{3}(\mathrm{pH} 8.0-10.0)$ and $\mathrm{Na}_{2}$ $\mathrm{HPO}_{4} / \mathrm{NaOH}$ (pH 10.0) (Gomori 1955). Spore formation was checked by incubating the strains using Tryptone Yeast Extract (TYE) agar supplemented with $5 \mathrm{mg} / \mathrm{M} \mathrm{MnSO}_{4}$ for 7 days at $30{ }^{\circ} \mathrm{C}$ (Verma et al. 2013). The Becton-Dickinson (BD) $\mathrm{GasPak}^{\mathrm{TM}} \mathrm{EZ}$ Gas Generating System was used to test anaerobic growth. Catalase activity was determined by the production of bubbles from $3 \%(\mathrm{v} / \mathrm{v}) \mathrm{H}_{2} \mathrm{O}_{2}$ solution mixed with freshly grown cells. Oxidase activity was checked by using of $1 \%(\mathrm{w} / \mathrm{v}) \mathrm{N}, \mathrm{N}, \mathrm{N}, \mathrm{N}$-tetramethyl$p$-phenylenediamine reagent (Sigma) according to the manufacturer's instructions. Triple sugar iron agar was used to test for $\mathrm{H}_{2} \mathrm{~S}$ production. Nitrate reduction was tested in nitrate broth containing $0.2 \% \mathrm{KNO}_{3}$ (Skerman 1967). Indole production was analyzed using Kovács's reagent in $1 \%$ tryptone broth (Skerman 1967). Hydrolysis of gelatin (on a medium containing $12 \%$ gelatin, $0.3 \%$ beef extract and $0.5 \%$ peptone), aesculin (on TSA containing $0.3 \%$ aesculin and $\mathrm{Fe}^{3+}$ ), Tween 20 and 80 (on TSA containing $1 \%$ Tween $20 / 80$ and $0.02 \% \mathrm{CaCl}_{2}$ ), starch (on TSA containing $1 \%$ starch) and casein (on TSA supplemented with $2 \%$ skim milk) were analyzed as previously described by Cowan and Steel (1974). Antibiotic susceptibility was tested by using Oxoid antibiotic paper discs on Mueller-Hinton (Difco) agar at $30{ }^{\circ} \mathrm{C}$ for $48 \mathrm{~h}$ under aerobic conditions as described by Bauer et al. (1966). The antibiotics were used included carbenicillin $\left(\mathrm{CAR}_{100}, 100 \mu \mathrm{g}\right)$, ceftazidime $\left(\mathrm{CAZ}_{30}, 30 \mu \mathrm{g}\right)$, novobiocin $\left(\mathrm{NV}_{30}, 30 \mu \mathrm{g}\right)$, neomycin $\left(\mathrm{N}_{30}, 30 \mu \mathrm{g}\right)$, tetracycline $\left(\mathrm{TE}_{30}, 30 \mu \mathrm{g}\right)$, cefazolin $\left(\mathrm{KZ}_{30}, 30 \mu \mathrm{g}\right)$, erythromycin $\left(\mathrm{E}_{15}, 15 \mu \mathrm{g}\right)$, oleandomycin $\left(\mathrm{OL}_{15}, 15 \mu \mathrm{g}\right)$, lincomycin $\left(\mathrm{L}_{15}, 15 \mu \mathrm{g}\right)$ and rifampicin $\left(\mathrm{RD}_{5}, 5 \mu \mathrm{g}\right)$ (Sigma-Aldrich). Zones of inhibition were interpreted according to the manufacturer's instruction. Basic chemical tests, carbon source assimilation and enzyme activities were conducted using API 20E (bioMérieux), API 50CHB (bioMérieux), GP VITEK-2 compact system version 4.01 (bioMérieux) and API ZYM (bioMérieux), according to the manufacturer's instructions. API 20E, API 50CHB, GP VITEK-2 compact system version 4.01 (bioMérieux) were recorded after incubation for $48 \mathrm{~h}$, under the optimal conditions for each strain while API ZYM was recorded after incubation for $10 \mathrm{~h}$.

\section{Molecular characterization}

The genomic DNA of strain DCY $84^{\mathrm{T}}$ was isolated by using a DNA isolation kit (Gene All Biotechnology, Republic of Korea). The 16S rRNA gene was amplified using the universal bacterial primer sets including 27F/1492R (Lane 1991) and 518F/800R (Weisburg et al. 1991). The purified PCR product was sequenced by Genotech (Daejeon, Republic of Korea) according to Kim et al. (2005). Seq-Man software version 4.1 (DNASTAR, Inc.) was used to compile the 16S rRNA sequence of strain DCY $84^{\mathrm{T}}$. The nearly complete $(1,474 \mathrm{bp}) 16 \mathrm{~S}$ rRNA sequence of strain DCY $84^{\mathrm{T}}$ was compiled using Seqman software and edited using the BioEdit program (Hall 1999). Multiple alignments were performed with the CLUSTAL X program (Thompson et al. 1997) and distances were calculated according to Kimura two-parameter model (Kimura 1983). Paenibacillus members with 16S rRNA gene sequence similarities above $94 \%$ were included in the phylogenetic tree. The phylogenetic tree was constructed with the neighbour-joining (Saitou and Nei 1987), maximum-parsimony (Fitch 1971) and maximum-likelihood (Felsenstein 1981) methods by using the MEGA 6 program package (Tamura et al. 2013). In order to determine the confidence levels for the branches, bootstrap analysis with 1,000 replications was conducted (Felsenstein 1985). The strain DCY $84^{\mathrm{T}}$ sequence obtained was compared with those in public databases by using the EzTaxon-e server (http:// eztaxon-e.ezbiocloud.net/; Kim et al. 2012) and NCBI database (http://blast.ncbi.nlm.nih.gov/Blast. cgi; Johnson et al. 2008). 
DNA G+C mol\% content

For DNA $\mathrm{G}+\mathrm{C}$ mol\% content analysis, the genomic DNA of strain DCY $84^{\mathrm{T}}$ and the closest related strain, P. barengoltzii KACC $15270^{\mathrm{T}}$, were extracted and purified by using an Exgene TM Cell SV mini-kit (Gene All Biotechnology, Republic of Korea) according to the manufacturer's instructions. Nuclease and alkaline phosphatase enzymes were used to degrade DNA into single nucleotides. The obtained nucleotide mixture was separated using HPLC [Model NS6000A, Futecs, reversed-phase column YMC-Triart $\mathrm{C} 18(4.6 \times 250 \mathrm{~mm} \times 5 \mu \mathrm{m})$, using a mixture of $0.02 \mathrm{M}\left(\mathrm{NH}_{4}\right) \mathrm{H}_{2} \mathrm{PO}_{4}$ and acetonitrile $(20: 1, \mathrm{v} / \mathrm{v})$ for the mobile phase, a flow rate of $1.2 \mathrm{ml} / \mathrm{min}$ and wavelength at $270 \mathrm{~nm}$ (Mesbah et al. 1989). The genomic DNA of Escherichia coli strain B (SigmaAldrich D4889) was used as a standard.

\section{Chemotaxonomic characterization}

For quinone analysis, cells were grown in TSB at $30{ }^{\circ} \mathrm{C}$, shaken at $160 \mathrm{rpm}$ for 1 day, centrifuged and freeze dried. Respiratory quinones were extracted from $100 \mathrm{mg}$ freeze-dried cells with chloroform/ methanol $(2 / 1, v / v)$, separated by using hexane and eluted with hexane/diethyl ether $(98 / 2$, v/v), then eluent was evaporated by a rotatory evaporator and the residue dissolved in acetone, according to Collins (1985). Menaquinones were analysed by reversephase HPLC (Model, NS-6000A Futecs, wavelength $270 \mathrm{~nm}$, solvent $\mathrm{MeOH}$ : Isopropanol = 7:3). Polar lipids of strain DCY $84^{\mathrm{T}}$ and P. barengoltzii KACC $15270^{\mathrm{T}}$ were analyzed as described by Minnikin et al. (1984). Separately, each sample was spotted on the corner of two-dimensional thin layer chromatography (2D-TLC) using TLC Kiesel gel $60 \mathrm{~F}_{254}$ (Merck) plates $(10 \times 10 \mathrm{~cm})$ and developed in the first direction by using of chloroform/methanol/water $(65 / 25 / 4$, by vol), then in the second direction developed by chloroform/ acetic acid/methanol/water $(80 / 15 / 12 / 4$, by vol). TLC plates were sprayed with $5 \%$ molybdatophosphoric acid to detect total lipids, $0.2 \%$ ninhydrin reagent to detect aminolipids and $15 \% \alpha$-naphthol reagent to detect glycolipids. After spraying, plates were heated at $120{ }^{\circ} \mathrm{C}$ for $10 \mathrm{~min}$. TLC plates were also sprayed with Molybdenum blue reagent for detection of phospholipids. For fatty acid analysis, the cells were grown on TSA at $30{ }^{\circ} \mathrm{C}$ for $24 \mathrm{~h}$. Fatty acids were extracted, methylated and saponified by the method described by the Sherlock Microbial Identification system (MIDI) and analyzed by capillary GLC (Hewlet Packard 6890) using the TSBA library version 6.1 (Sasser 1990). Fatty acid analysis was performed in duplicate.

The peptidoglycan of strain DCY $84^{\mathrm{T}}$ and P. barengoltzii KACC $15270^{\mathrm{T}}$ was analyzed as described by Schleifer (1985). The hydrolysed peptidoglycans were analysed by spotting the samples on cellulose Merck KGaA $(20 \times 20 \mathrm{~cm})$ TLC plates. The modified TLC solvent Methanol/Pyridine/HCl (12 N)/water (32/4/1/7, by vol) was prepared 1 day before running the analysis (Schumann 2011). The polyamines of strain DCY $84^{\mathrm{T}}$ and $P$. barengoltzii KACC $15270^{\mathrm{T}}$ were extracted as described elsewhere (Taibi et al. 2000). Samples were analyzed by using HPLC using a reversed-phase Eclipse C18 column $\left(30 \times 50 \mathrm{~mm}^{2} \times 2.7 \mathrm{~mm}\right)$ with $60 \%$ methanol and wavelength $234 \mathrm{~nm}$ (Scherer and Kneifel 1983). To analyze the whole cell sugars of strain DCY $84^{\mathrm{T}}$ and $P$. barengoltzii KACC $15270^{\mathrm{T}}$, freeze dried cells were collected and hydrolysed in $1 \mathrm{~N} \mathrm{H}_{2} \mathrm{SO}_{4}$ for $2 \mathrm{~h}$ at $100{ }^{\circ} \mathrm{C}$. After cooling, the $\mathrm{pH}$ of the samples $\mathrm{pH}$ was adjusted by adding saturated $\mathrm{Ba}(\mathrm{OH})_{2}$ and methyl red solution as $\mathrm{pH}$ indicator. After centrifugation, the liquid phase was taken and dried in a freeze drier. The released sugars were detected by spotting $10 \mu \mathrm{l}$ samples and $5 \mu \mathrm{l}$ of a standard mixture of sugars as reference on TLC plates (TLC cellulose Merck $\mathrm{KGaA}, 20 \times 20 \mathrm{~cm}$ ) developed by using the solvent 1-butanol/pyridine/water (5/3/2, by vol) (Staneck and Roberts 1974).

In vitro assessment of plant growth promoting traits

The DCY $84^{\mathrm{T}}$ isolate was also evaluated for the presence of desirable plant growth promoting characteristics. To assess indole-3-acetic acid (IAA) production, the method described by Glickmann and Dessaux (1995) was used. Some modifications for in vitro IAA production were performed by using modified King B broth (Casein $10 \mathrm{~g} / \mathrm{l}$, Peptone no.3 $10 \mathrm{~g} / \mathrm{l}$, dipotassium phosphate $1.5 \mathrm{~g} / \mathrm{l}$, magnesium sulfate $1.5 \mathrm{~g} / \mathrm{l})$ media with and without additional L-tryptophan $(3 \mathrm{mg} / \mathrm{ml})$, as described by Shokri and Emtiazi (2010). The production of IAA was measured after 6 days of incubation. Qualitative test of phosphate solubilizing ability of strain $\mathrm{DCY} 84^{\mathrm{T}}$ was checked by plate 
screening methods and the media were prepared manually as described by Pikovskaya (1948). Strain DCY $84^{\mathrm{T}}$ was also analyzed for its siderophore production capacity in petri dishes containing Pseudomonas Agar F (Difco) medium (Glickmann and Dessaux 1995) supplemented with a chrome azurol S complex [CAS/iron(III)/hexadeciltrimethyl ammonium bromide], as described by Schwyn and Neilands (1987).

\section{Results and discussion}

The comparison of the 16S rRNA sequence of strain DCY84 ${ }^{\mathrm{T}}$ (GenBank/EMBL/DDBJ accession number KF915796) with other Paenibacillus strains revealed that strain DCY $84^{\mathrm{T}}$ is a novel strain of the genus Paenibacillus, sharing highest sequence similarity with $P$. barengoltzii KACC $15270^{\mathrm{T}}(96.86 \%)$, followed by $P$. timonensis KACC $11491^{\mathrm{T}}(96.49 \%)$ and P. phoenicis NBRC $106274^{\mathrm{T}}(95.77 \%)$. The similarities with other type strains of the genus Paenibacillus were 91.87-96.49\%. A neighbour-joining phylogenetic tree based on 16S rRNA gene sequences showing the position of strain DCY84 $4^{\mathrm{T}}$ in the genus Paenibacillus was constructed (Fig. 1). The topologies of the phylogenetic trees built using maximum-parsimony method also supported the conclusion that strain DCY $84^{\mathrm{T}}$ forms a stable clade with the type strain $P$. barengoltzii KACC $15270^{\mathrm{T}}$ (Fig. 1). The phylogenetic trees built using maximum-likelihood method are also available as Supplementary Fig. S1. On the basis of sequence analysis, it is evident that the novel strain belongs to the genus Paenibacillus.

The DNA G $+\mathrm{C}$ content of strain $\mathrm{DCY} 84^{\mathrm{T}}$ was determined to be $62.6 \mathrm{~mol} \%$, indicating it can be considered to belong to the high-G+C lineage (56-63\%) within the genus Paenibacillus, together with Paenibacillus soli DCY03 ${ }^{\mathrm{T}}(56.8 \pm 0.2 \mathrm{~mol} \%$, Park et al. 2007), Paenibacillus humicus PC-147 ${ }^{\mathrm{T}}$ (58.3 $\pm 0.3 \mathrm{~mol} \%$, Vaz-Moreira et al. 2007) and Paenibacillus pasadenensis NBRC $101214^{\mathrm{T}}$ (63.4 $\pm 0.6 \mathrm{~mol} \%$, Vaz-Moreira et al. 2007).

Morphological observation of strain $\mathrm{DCY} 84^{\mathrm{T}}$ colonies on TSA agar revealed white, round, smooth and raised colonies with approximate diameters $2-5 \mathrm{~mm}$ after incubation at $30{ }^{\circ} \mathrm{C}$ for $48 \mathrm{~h}$. Strain DCY $84^{\mathrm{T}}$ was found to grow on LB, TSA, R2A and NA, but not to grow on PDA and MacConkey agar. The strain was observed to grow best in TSA at temperatures of $15-40{ }^{\circ} \mathrm{C}$; at $\mathrm{pH} 5-9$ and at $0.5-4.5 \% \mathrm{NaCl}$ (optimum, $0.5 \%$ ). Optimum growth occurs at $25-30{ }^{\circ} \mathrm{C}$ and $\mathrm{pH} 7-8$. Phenotypic analysis showed that strain DCY $84^{\mathrm{T}}$ cells are Gram-positive, motile, aerobic and rod shaped with size range approximately $0.7-0.9 \times 3.4-4.7 \mu \mathrm{m}$. Peritrichous flagella were observed by using TEM (Supplementary Fig. S2). Strain DCY $84^{\mathrm{T}}$ was also found to produce ellipsoidal endospores. Endospore formation is a general characteristic of members of the family Bacillaceae (Logan et al. 2009). Tests for oxidase activity and $\mathrm{H}_{2} \mathrm{~S}$ production were negative, whilst catalase activity and indole test was found to be positive. Strain DCY $84^{\mathrm{T}}$ is not able to hydrolyse casein and DNA but is able to hydrolyse starch, Tween 20, Tween 80 , gelatin and aesculin. Nitrate was not found to be reduced to nitrite. The biochemical and physiological characteristics of strain $\mathrm{DCY} 84^{\mathrm{T}}$ and nearest Paenibacillus strains are shown on Table 1.

Strain DCY $84^{\mathrm{T}}$ is susceptible to all antibiotics tested in this study, notably to ceftazidime $\left(\mathrm{CAZ}_{30}\right.$, $30 \mu \mathrm{g})$ and erythromycin $\left(\mathrm{E}_{15}, 15 \mu \mathrm{g}\right)$. In addition, strain DCY84 ${ }^{\mathrm{T}}$ was found to susceptible to carbenicillin $\left(\mathrm{CAR}_{100}, 100 \mu \mathrm{g}\right)$, novobiocin $\left(\mathrm{NV}_{30}, 30 \mu \mathrm{g}\right)$, neomycin $\left(\mathrm{N}_{30}, 30 \mu \mathrm{g}\right)$, tetracycline $\left(\mathrm{TE}_{30}, 30 \mu \mathrm{g}\right)$, cefazolin $\left(\mathrm{KZ}_{30}, 30 \mu \mathrm{g}\right)$, oleandomycin $\left(\mathrm{OL}_{15}, 15 \mu \mathrm{g}\right)$, lincomycin $\left(\mathrm{L}_{15}, 15 \mu \mathrm{g}\right)$ and rifampicin $\left(\mathrm{RD}_{5}, 5 \mu \mathrm{g}\right)$. Furthermore, strain DCY $84^{\mathrm{T}}$ was also found to be resistant to bacitracin and optochin, but susceptible to novobiocin, O/129 (2,4-diamino-6,7-diisopropylpteridine) and polymyxin B (according GP VITEK-2).

Both strain $\mathrm{DCY} 84^{\mathrm{T}}$ and $P$. barengoltzii KACC $15270^{\mathrm{T}}$ were shown to have MK-7 as the only isoprenoid quinone detected. As shown in Fig. 2, the major polar lipids were identified as phosphatidylethanolamine (PE), an unidentified aminophospholipid (APL), unidentified aminolipids (AL1, AL2) and an unidentified polar lipid (L1). This profile is similar to the polar lipids of $P$. barengoltzii KACC $15270^{\mathrm{T}}$ which has two additional unidentified polar lipids among its major polar lipids. The cell wall peptidoglycan of strain DCY $84^{\mathrm{T}}$ was found to contain mesodiaminopimelic acids, alanine and D-glutamic acid, which is similar with $P$. barengoltzii KACC $15270^{\mathrm{T}}$. The major fatty acids of strain DCY $84^{\mathrm{T}}$ were identified as branched chain anteiso- $\mathrm{C}_{15: 0}(32.1 \%)$, saturated $\mathrm{C}_{16: 0}(20.1 \%)$ and branched chain anteiso- $\mathrm{C}_{17: 0}$ $(18.3 \%)$,as has also been seen in $P$. barengoltzii 


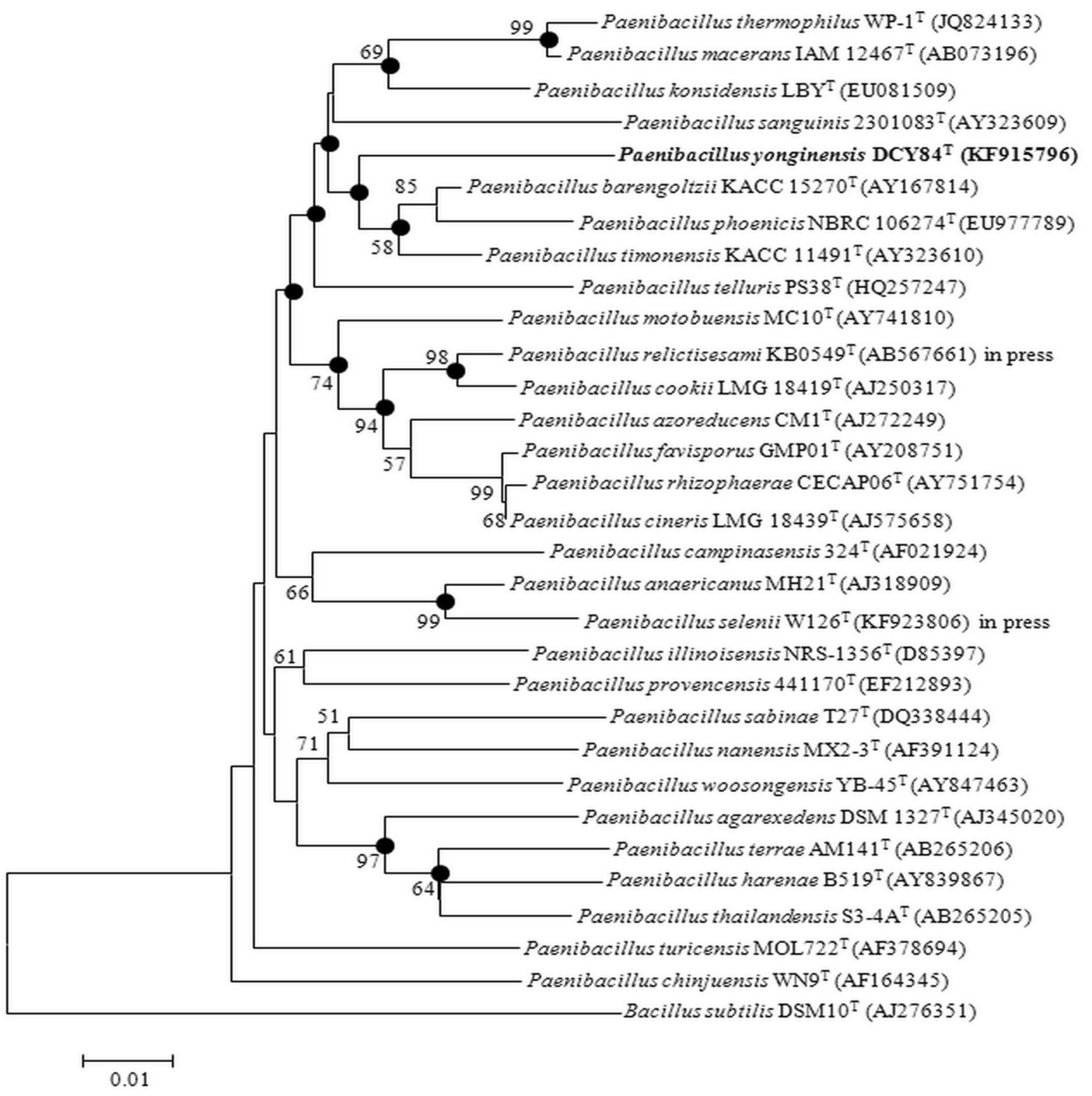

Fig. 1 16S rRNA gene sequence analysis showing phylogenetic relationships of strain $\mathrm{DCY} 84^{\mathrm{T}}$ and members of the genus Paenibacillus (neighbour-joining tree). Filled circles indicate that the corresponding nodes were also recovered in the tree

KACC $15270^{\mathrm{T}}$, P. timonensis KACC $11491^{\mathrm{T}}$ and $P$. phoenicis NBRC $106274^{\mathrm{T}}$. The proportion of anteiso$\mathrm{C}_{15: 0}$, anteiso- $\mathrm{C}_{17: 0}$ and $\mathrm{C}_{16: 0}$ was significantly different from that in the closely related species. Anteiso$\mathrm{C}_{\text {17:0 }}$ from strain DCY $84^{\mathrm{T}}$ was the highest $(18.3 \%$ ), while iso- $\mathrm{C}_{16: 0}$ from strain $\mathrm{DCY} 84^{\mathrm{T}}$ was the lowest $(9.0 \%)$, compared with other reference strains. The generated with the maximum-parsimony algorithm. Bootstrap values more than $50 \%$ based on 1,000 replications are shown at branching points. Bacillus subtilis DSM10 ${ }^{\mathrm{T}}$ was used as an group. Scale bar, 0.005 substitutions per nucleotide position

cellular fatty acid profile of strain DCY $84^{\mathrm{T}}$ and the related reference strains are shown on Table 2. The polyamine pattern of strain DCY $84^{\mathrm{T}}$ was found to be the same as that of $P$. barengoltzii KACC $15270^{\mathrm{T}}$. Both of these strains have spermidine as predominant polyamine. Cell wall sugars of the strain DCY $84^{\mathrm{T}}$ were identified as ribose, galactose and xylose, while 
Table 1 The different biochemical, physiological and in vitro plant growth promoting characteristics of strain DCY84 ${ }^{\mathrm{T}}$ and the reference strains of the genus Paenibacillus

\begin{tabular}{|c|c|c|c|c|}
\hline Characteristics & 1 & 2 & 3 & 4 \\
\hline Bacitracin resistance & + & - & - & + \\
\hline \multicolumn{5}{|l|}{ Hydrolysis of } \\
\hline Cyclodextrin & + & - & + & - \\
\hline Salicin & + & - & + & + \\
\hline Inulin & - & + & + & - \\
\hline Gelatin (bovine origin) & + & - & - & - \\
\hline Glycogen & - & + & + & + \\
\hline Potassium gluconate & - & + & + & + \\
\hline Dulcitol & - & - & + & - \\
\hline Xylitol & - & - & + & - \\
\hline \multicolumn{5}{|l|}{ Enzyme activity } \\
\hline Naphthol-AS-BI-phosphohydrolase & $\mathrm{w}$ & $\mathrm{w}$ & + & $\mathrm{w}$ \\
\hline Methyl $\beta$-D-xylopyranoside & $\mathrm{w}$ & $\mathrm{w}$ & + & + \\
\hline Methyl- $\beta$-D-glucopyranoside & + & - & + & + \\
\hline Methyl $\alpha$-D-mannopyranoside & - & $\mathrm{w}$ & $\mathrm{w}$ & + \\
\hline$\alpha$-fucosidase & $\mathrm{w}$ & - & - & - \\
\hline$\beta$-galactopyranosidase & + & + & - & - \\
\hline$\alpha$-chymotrypsin & + & - & $\mathrm{w}$ & - \\
\hline Lipase & - & + & + & $\mathrm{w}$ \\
\hline Leucine arylamidase & + & + & + & - \\
\hline Alanine arylamidase & + & - & - & - \\
\hline Tyrosine arylamidase & + & + & + & - \\
\hline Aminoexotripeptidase & - & + & - & - \\
\hline L-Aspartate arylamidase & + & + & - & + \\
\hline L-Pyrrolidonyl arylamidase & + & - & - & - \\
\hline $\mathrm{N}$-acetyl-D-glucosaminidase & + & - & + & $\mathrm{w}$ \\
\hline \multicolumn{5}{|l|}{ Assimilation of } \\
\hline D-Xylose & + & - & + & + \\
\hline D-Ribose & + & - & + & - \\
\hline D-Melezitose & - & - & $\mathrm{w}$ & - \\
\hline D-Turanose & + & - & $\mathrm{w}$ & - \\
\hline D-Lyxose & - & - & + & - \\
\hline D-Arabitol & - & - & + & - \\
\hline D-Mannitol & + & + & + & - \\
\hline L-Fucose & - & - & $\mathrm{w}$ & $\mathrm{w}$ \\
\hline L-Sorbose & - & - & + & - \\
\hline D-Lactose & + & - & + & + \\
\hline Saccharose/sucrose & + & + & + & - \\
\hline $\mathrm{N}$-acetyl-D-glucosamine & + & - & + & + \\
\hline \multicolumn{5}{|l|}{ In vitro plant growth promoting traits } \\
\hline IAA production w/o L-tryptophan $(\mu \mathrm{g} / \mathrm{ml})$ & $52.96 \pm 1.85$ & $50.22 \pm 0.45$ & $12.27 \pm 0.7$ & $29.54 \pm 1.05$ \\
\hline IAA production with L-tryptophan $(\mu \mathrm{g} / \mathrm{ml})$ & $72.83 \pm 2.26$ & $70.82 \pm 1.91$ & $32.87 \pm 4.57$ & $56.96 \pm 3.55$ \\
\hline Siderophore production & + & + & $\mathrm{w}$ & + \\
\hline
\end{tabular}


Table 1 continued

\begin{tabular}{lllll}
\hline Characteristics & 1 & 2 & 3 & 4 \\
\hline $\begin{array}{c}\text { Phosphate } \\
\text { solubilization }\end{array}$ & + & + & - & - \\
\hline
\end{tabular}

Strain 1, Paenibacillus yonginensis DCY84 ${ }^{\mathrm{T}}$; 2, Paenibacillus barengoltzii $\mathrm{KACC} 15270^{\mathrm{T}} ; 3$, Paenibacillus phoenicis NBRC $106274^{\mathrm{T}}$; 4, Paenibacillus timonensis KACC $11491^{\mathrm{T}}$

All strains are positive for arbutin, aesculin, gentiobiose, starch, optochin resistance, acetoin production (Voges Proskauer), indole production, citrate utilization, D-amygdalin, D-cellobiose, D-fructose, D-galactose, D-glucose, D-mannose, D-maltose, D-melibiose, Draffinose, D-trehalose, L-arabinose, methyl $\alpha$-D-glucopyranoside, $N$-acetylglucosamine, tryptophandeaminase, $\alpha$-glucosidase, $\beta$ glucosidase, $\alpha$-galactosidase, $\beta$-galactosidase, esterase and esterase lipase. All strains are negative for glycerol, erythritol, inositol, pullulan, potassium 2-ketogluconate, potassium 5-ketogluconate, L-lactate alkalinization, novobiocin resistance, polymyxin B resistance, O/129 (2,4-diamino-6,7-diisopropylpteridine) resistance, growth in $6.5 \% \mathrm{NaCl}, \mathrm{H} 2 \mathrm{~S}$ production, D-sorbitol, D-adonitol, Darabinose, D-tagatose, D-fucose, L-xylose, L-rhamnose, L-arabitol, $\alpha$-mannosidase, $\beta$-glucuronidase, urease, trypsin, arginine dihydrolase, arginine dihydrolase 2, alkaline phosphatase, valine arylamidase, cystine arylamidase, L-proline arylamidase, lysine decarboxylase, ornithine decarboxylase, acid phosphatase, phosphatase and phosphatidylinositol phospholipase C

+ Positive result, w weakly positive, - negative result

a

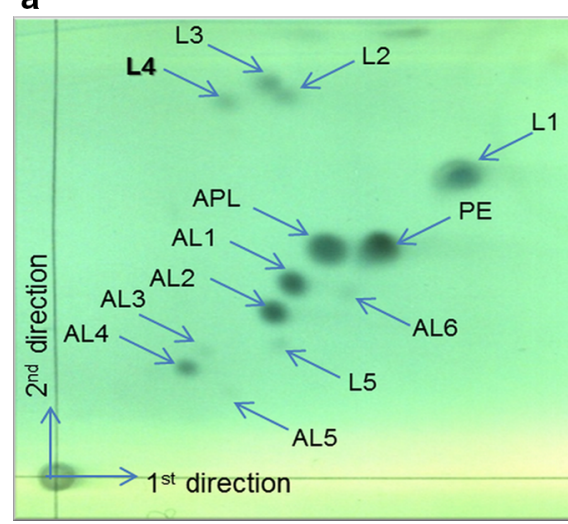

Fig. 2 Two-dimensional TLC of the total polar lipids of Paenibacillus yonginensis $\mathrm{DCY} 84^{\mathrm{T}}$ (a) and Paenibacillus barengoltzii KACC $15270^{\mathrm{T}}$ (b), stained for total polar lipids

P. barengoltzii KACC $15270^{\mathrm{T}}$ was found to contain ribose, rhamnose and glucose.

Regarding the plant growth promoting characteristics, strain $\mathrm{DCY} 84^{\mathrm{T}}$ was found to produce $52.96 \pm 1.85 \mu \mathrm{g} / \mathrm{ml}$ (without L-tryptophan) and $72.83 \pm 2.86 \mu \mathrm{g} / \mathrm{ml}$ (with L-tryptophan) IAA, respectively. Clear halo regions observed around the colonies on opaque Pikovskaya medium indicated positive results for the phosphate solubilization test (Supplementary Fig. S3). Moreover, strain DCY $84^{\mathrm{T}}$ was able to produce siderophores as was confirmed by the development of yellow halo zones surrounding the colonies on blue-green coloured medium (Supplementary Fig. S3). A comparison of the in vitro plant growth promoting characteristics of strain DCY $84^{\mathrm{T}}$ b

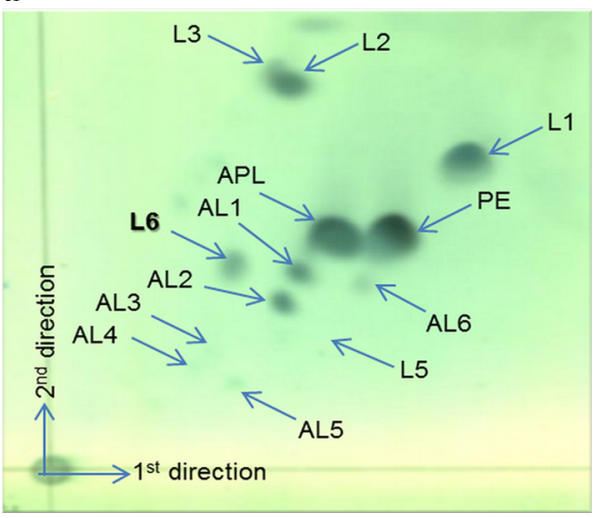

with $5 \%$ ethanolic molybdophosphoric acid. APL aminophospholipid, $P E$ phosphatidylethanolamine, AL1-6 unidentified aminolipids, L1-5 unidentified polar lipids

and the reference strains of genus Paenibacillus is shown on Table 1.

On the basis of the phylogenetic, phenotypic and chemotaxonomic data, strain DCY $84^{\mathrm{T}}$ (=KCTC $33428^{\mathrm{T}}=\mathrm{JCM} 19885^{\mathrm{T}}$ ) is considered to represent a novel species of the genus Paenibacillus, for which name Paenibacillus yonginensis sp. nov. is proposed.

\section{Description of Paenibacillus yonginensis sp. nov}

Paenibacillus yonginensis (yon.gi.nen'sis. N.L. masc. adj. yonginensis of or belonging to Yongin, Korea, from where the type strain was isolated) 
Table 2 Chemotaxonomic profiles of strain $\mathrm{DCY}^{\mathrm{T}} 4^{\mathrm{T}}$ and related species of the genus Paenibacillus

\begin{tabular}{|c|c|c|c|c|}
\hline & 1 & 2 & 3 & 4 \\
\hline \multicolumn{5}{|l|}{ Fatty acid } \\
\hline \multicolumn{5}{|l|}{ Saturated } \\
\hline $\mathrm{C}_{12: 0}$ & 0.6 & 2.8 & 2.1 & 2.4 \\
\hline $\mathrm{C}_{14: 0}$ & 6.9 & 12.0 & 6.3 & 10.8 \\
\hline $\mathrm{C}_{16: 0}$ & 20.2 & 31.6 & 21.4 & 23.3 \\
\hline $\mathrm{C}_{18: 0}$ & 0.9 & $\operatorname{tr}$ & $\operatorname{tr}$ & $\operatorname{tr}$ \\
\hline \multicolumn{5}{|c|}{ Branched-chain } \\
\hline iso- $\mathrm{C}_{14: 0}$ & 0.7 & 0.9 & 1.1 & 2.2 \\
\hline iso- $\mathrm{C}_{15: 0}$ & 4.9 & 2.6 & 5.1 & 3.5 \\
\hline iso- $\mathrm{C}_{16: 0}$ & 9.0 & 13.1 & 10.6 & 18.6 \\
\hline iso- $\mathrm{C}_{17: 0}$ & 3.6 & 2.7 & 3.7 & 3.5 \\
\hline $\begin{array}{c}\text { anteiso- } \\
\mathrm{C}_{13: 0}\end{array}$ & $\operatorname{tr}$ & $\operatorname{tr}$ & 0.7 & $\operatorname{tr}$ \\
\hline $\begin{array}{c}\text { anteiso- } \\
\mathrm{C}_{15: 0}\end{array}$ & 32.1 & 22.2 & 33.4 & 24.7 \\
\hline $\begin{array}{c}\text { anteiso- } \\
\mathrm{C}_{17: 0}\end{array}$ & 18.3 & 9.8 & 13.0 & 8.9 \\
\hline $\mathrm{C}_{18: 1} \omega 7 \mathrm{c}$ & 0.5 & - & $\operatorname{tr}$ & - \\
\hline $\begin{array}{l}\text { Summed } \\
\text { feature } 5^{*}\end{array}$ & 0.9 & $\operatorname{tr}$ & $\operatorname{tr}$ & - \\
\hline $\begin{array}{l}\text { Cell wall } \\
\text { sugar }\end{array}$ & $\begin{array}{l}\text { Ribose } \\
\text { galactose } \\
\text { xylose }\end{array}$ & $\begin{array}{l}\text { Ribose } \\
\text { rhamnose } \\
\text { glucose }\end{array}$ & ND & ND \\
\hline $\begin{array}{l}\text { Major } \\
\text { Polyamine }\end{array}$ & Spermidine & Spermidine & ND & ND \\
\hline
\end{tabular}

Strain 1, Paenibacillus yonginensis DCY84 ${ }^{\mathrm{T}} ; 2$, Paenibacillus barengoltzii KACC $15270^{\mathrm{T}}$; 3, Paenibacillus phoenicis NBRC $106274^{\mathrm{T}}$; 4, Paenibacillus timonensis KACC $11491^{\mathrm{T}}$

For fatty acid analysis, all type strains were collected after $24 \mathrm{~h}$ of growth on TSA medium (Difco) at $30^{\circ} \mathrm{C}$. Summed feature 5 could not be separated by the Microbial Identification System (MIDI). Fatty acids amounting to $<0.5 \%$ in all strains were not listed

Summed feature $5^{*}$ consisted of anteiso- $\mathrm{C}_{18: 0}$ and/or $\mathrm{C}_{18: 2}$ $\omega 6,9 \mathrm{c}$ and/or $\mathrm{C}_{18: 1} \omega 9 \mathrm{c}$

- not detected, $\operatorname{tr}$ trace amount $(<0.5 \%), N D$ no data

Gram-stain positive, rod-shaped, aerobic and motile by peritrichous flagella. Vegetative cells are approximately $0.7-0.9 \mu \mathrm{m}$ in width and 3.4-4.7 $\mu \mathrm{m}$ in length. Colonies formed after $48 \mathrm{~h}$ of growth on TSA at $30{ }^{\circ} \mathrm{C}$ are white, round, smooth, raised, have a diameter of $2-5 \mathrm{~mm}$, show no pigmentation and possess entire edges. Grows on LB, TSA, R2A and NA, but does not grow on PDA and MacConkey agar. Cells can grow in TSA over the temperature range of
$15-40{ }^{\circ} \mathrm{C}$, at $\mathrm{pH}$ range $5-9$ and at $0.5-4.5 \% \mathrm{NaCl}$. Optimal growth is observed in TSA at $30{ }^{\circ} \mathrm{C}, \mathrm{pH} 8$ and $0.5 \% \mathrm{NaCl}$. Does not hydrolyse casein and DNA agar but is able to hydrolise starch, Tween 20, Tween 80 , gelatin and aesculin. Tests for nitrate reduction, oxidase and $\mathrm{H}_{2} \mathrm{~S}$ production are negative, while catalase, indole and acetoin production are positive. Assimilation of the following sole carbon sources is positive: D-xylose, D-ribose, D-turanose, D-mannitol, Damygdalin, D-cellobiose, D-fructose, D-galactose, Dglucose, D-mannose, D-maltose, D-melibiose, D-raffinose, D-trehalose, D-lactose, L-arabinose, saccharose and $\mathrm{N}$-acetyl-D-glucosamine. Assimilation of the following sole carbon sources is negative: D-melezitose, D-lyxose, D-arabitol, D-fucose, D-sorbitol, D-adonitol, D-arabinose, D-tagatose, L-fucose, L-arabitol, L-xylose, L-sorbose and L-rhamnose. Methyl $\alpha$-D-glucopyranoside, Methyl $\beta$-D-glucopyranoside, $N$-acetylglucosamine, tryptophandeaminase, $\alpha$-glucosidase, $\alpha$ galactosidase, $\alpha$-chymotrypsin, $\beta$-glucosidase, $\beta$ galactosidase, $\beta$-galactopyranosidase, leucine arylamidase, alanine arylamidase, tyrosine arylamidase, Laspartate arylamidase, L-pyrrolidonyl arylamidase, $\mathrm{N}$ acetyl-D-glucosaminidase, esterase and esterase lipase are produced but methyl $\alpha$-D-mannopyranoside, lipase, aminoexotripeptidase, $\alpha$-mannosidase, $\beta$-glucuronidase, urease, trypsin, arginine dihydrolase, arginine dihydrolase 2, alkaline phosphatase, valine arylamidase, cystine arylamidase, L-proline arylamidase, lysine decarboxylase, ornithine decarboxylase, acid phosphatase, phosphatase and phosphatidylinositol phospholipase $\mathrm{C}$ are absent. Naphthol-AS-BIphosphohydrolase, methyl $\beta$-D-xylopyranoside and $\alpha$ fucosidase are weakly produced. Able to utilize arbutin, gentiobiose, salicin, cyclodextrin and citrate but not able to utilize inulin, glycogen, potassium gluconate, dulcitol, xylitol, glycerol, erythritol, inositol, pullulan, potassium 2-ketogluconate, potassium 5-ketogluconate and L-lactate. MK-7 menaquinone is the isoprenoid quinone. The major polar lipids are phosphatidylethanolamine, an unidentified aminophospholipid, two unidentified aminolipids and an unidentified polar lipid. The cell wall contains mesodiaminopimelic acid, alanine and $\mathrm{D}$-glutamic acid. The major fatty acids are branched chain anteiso- $\mathrm{C}_{15: 0}$, saturated $\mathrm{C}_{16: 0}$ and branched chain anteiso- $\mathrm{C}_{17: 0}$. Spermidine is found as the predominant polyamine. Cell wall sugars contain ribose, galactose and xylose. 
The DNA G+C content of the type strain, $\mathrm{DCY} 84^{\mathrm{T}}$, is $62.6 \mathrm{~mol} \%$.

The type strain is DCY $84^{\mathrm{T}} \quad(=\mathrm{KCTC}$ $33428^{\mathrm{T}}=\mathrm{JCM} 19885^{\mathrm{T}}$ ) was isolated from humus soil of a Yongin forest of Gyeonggi province in South Korea. The GenBank/EMBL/DDBJ accession number for the 16S rRNA gene sequence of strain DCY $84^{\mathrm{T}}$ is KF915796.

Acknowledgments This research was supported by Korea Institute of Planning \& Evaluation for Technology in Food, Agriculture, Forestry \& Fisheries (KIPET NO: 309019-03-3SB010) and Next-Generation BioGreen 21 Program (SSAC, grant\#: PJ009529032014), Republic of Korea.

\section{References}

Ash C, Farrow JAE, Wallbanks S, Collins MD (1991) Phylogenetic heterogeneity of the genus Bacillus as revealed by comparative analysis of small-subunit-ribosomal RNA sequences. Lett Appl Microbiol 13:202-206

Bauer AW, Kirby WMM, Sherris JC, Turck M (1966) Antibiotic susceptibility testing by a standardized single disk method. Am J Clin Pathol 45:493-496

Benardini JN, Vaishampayan PA, Schwendner P, Swanner E, Fukui Y, Osman S, Satomi M, Venkateswaran K (2011) Paenibacillus phoenicis sp. nov., isolated from the Phoenix Lander assembly facility and a subsurface molybdenum mine. Int J Syst Evol Microbiol 61:1338-1343

Beneduzi A, Costa PB, Parma M, Melo IS, Bodanese-Zanettini MH, Passaglia LM (2010) Paenibacillus riograndensis sp. nov., a nitrogen-fixing species isolated from the rhizosphere of Triticum aestivum. Int J Syst Evol Microbiol 60:128-133

Carro L, Flores-Félix JD, Cerda-Castillo E, Ramírez-Bahena MH, Igual JM, Tejedor C, Velázquez E, Peix A (2013) Paenibacillus endophyticus sp. nov., isolated from nodules of Cicer arietinum. Int J Syst Evol Microbiol 63:4433-4438

Collins MD (1985) Isoprenoid quinone analyses in bacterial classification and identification. In: Goodfellow M, Minnikin DE (eds) Chemical methods in bacterial systematics. Academic Press, London, pp 267-287

Cowan ST, Steel KJ (1974) Manual for the identification of medical bacteria, 3rd edn. Cambridge University Press, Cambridge

Dsouza M, Taylor MW, Ryan J, MacKenzie A, Lagutin K, Anderson RF, Turner SJ, Aislabie J (2014) Paenibacillus darwinianus sp. nov., isolated from gamma-irradiated Antarctic soil. Int J Syst Evol Microbiol 64:1406-1411

Felsenstein J (1981) Evolutionary trees from DNA sequences: a maximum likelihood approach. J Mol Evol 17:368-376

Felsenstein J (1985) Confidence limits on phylogenies: an approach using the bootstrap. Evolution 39:783-791

Fitch WM (1971) Toward defining the course of evolution: minimum change for a specific tree topology. Syst Zool 20:406-416
Glickmann E, Dessaux Y (1995) A critical examination of the specificity of the Salkowski reagent for indolic compounds produced by phytopathogenic bacteria. Appl Environ Microbiol 61:793-796

Gomori G (1955) Preparation of buffers for use in enzyme studies. In: Colowick SP, Kaplan NO (eds) Methods in enzymology. Academic Press, New York, pp 138-146

Hall TA (1999) BioEdit: a user-friendly biological sequence alignment editor and analysis program for Windows 95/98/ NT. Nucleic Acids Symp Ser 41:95-98

Hayat R, Ali S, Amara U, Khalid R, Ahmed I (2010) Soil beneficial bacteria and their role in plant growth promotion: a review. Ann Microbiol 60:579-598

Johnson M, Zaretskaya I, Raytselis Y, Merezhuk Y, McGinnis S, Madden TL (2008) NCBI BLAST: a better web interface. Nucleic Acids Res 1:36 (Web Server issue):W5-9. doi: 10.1093/nar/gkn201

Kim MK, Im WT, Ohta H, Lee M, Lee ST (2005) Sphingopyxisgranuli sp. nov., a $\beta$-glucosidase-producing bacterium in the family Sphingomonadaceae in $\alpha-4$ subclass of the Proteobacteria. J Microbiol 43:152-157

Kim OS, Cho YJ, Lee K, Yoon SH, Kim M, Na H, Park SC, Jeon YS, Lee JH, Yi H, Won S, Chun J (2012) Introducing EzTaxon-e: a prokaryotic 16S rRNA Gene sequence database with phylotypes that represent uncultured species. Int J Syst Evol Microbiol 62:716-721

Kimura M (1983) The neutral theory of molecular evolution. Cambridge University Press, Cambridge

Lane DJ (1991) 16S/23S rRNA sequencing. In: Stackebrandt E, Goodfellow M (eds) Nucleic acid techniques in bacterial systematics. Wiley, Chichester, pp 115-176

Logan NA, Berge O, Bishop AH, Busse HJ, De Vos P, Fritze D, Heyndrickx M, Kämpfer P, Rabinovitch L, Salkinoja-Salonen MS, Seldin L, Ventosa A (2009) Proposed minimal standards for describing new taxa of aerobic, endosporeforming bacteria. Int J Syst Evol Microbiol 59:2114-2121

Mesbah M, Premachandran U, Whitman WB (1989) Precise measurement of the $\mathrm{G}+\mathrm{C}$ content of deoxyribonucleic acid by high performance liquid chromatography. Int J Syst Bacteriol 39:159-167

Minnikin DE, ODonnell AG, Goodfellow M, Alderson G, Athalye M, Schaal A, Parlett JH (1984) An integrated procedure for the extraction of bacterial isoprenoid quinones and polar lipids. J Microbiol Methods 2:233-241

Montes MJ, Mercade E, Bozal N, Guinea J (2004) Paenibacillus antarcticus sp. nov., a novel psychrotolerant organism from the Antarctic environment. Int J Syst Evol Microbiol 54:1521-1526

Osman S, Satomi M, Venkateswaran K (2006) Paenibacillus pasadenensis sp. nov. and Paenibacillus barengoltzii sp. nov., isolated from a spacecraft assembly facility. Int J Syst Evol Microbiol 56:1509-1514

Park MJ, Kim HB, An DS, Yang HC, Oh ST, Chung HJ, Yang DC (2007) Paenibacillus soli sp. nov., a xylanolytic bacterium isolated from soil. Int $\mathrm{J}$ Syst Evol Microbiol 57:146-150

Park DS, Jeong WJ, Lee KH, Oh HW, Kim BC, Bae KS, Park HY (2009) Paenibacillus pectinilyticus sp. nov., isolated from the gut of Diestrammena apicalis. Int J Syst Evol Microbiol 59:1342-1347 
Pikovskaya RI (1948) Mobilization of phosphorus in soil in connection with vital activity of some microbial species. Mikrobiologya 17:362-370

Priest FG (2009) Genus I. Paenibacillus. In: DeVos P, Garrity G, Jones D, Krieg NR, Ludwig W, Rainey FA, Schleifer KH, Whitman WB (eds) Bergey's manual of systematic bacteriology, vol 2, 2nd edn. Springer, New York, pp 269-296

Saha P, Mondal AK, Mayilraj S, Krishnamurthi S, Bhattacharya A, Chakrabarti T (2005) Paenibacillus assamensis sp. nov., a novel bacterium isolated from a warm spring in Assam, India. Int J Syst Evol Microbiol 55:2577-2581

Saitou N, Nei M (1987) The neighbor-joining method: a new method for reconstructing phylogenetic trees. Mol Biol Evol 4:406-425

Sánchez MM, Fritze D, Blanco A, Spröer C, Tindall BJ, Schumann P, Kroppenstedt RM, Diaz P, Pastor FI (2005) Paenibacillus barcinonensis sp. nov., a xylanase-producing bacterium isolated from a rice field in the Ebro River delta. Int J Syst Evol Microbiol 55:935-939

Sasser M (1990) Identification of bacteria by gas chromatography of cellular fatty acids, MIDI Technical Note 101 . DE: MIDI Inc, Newark

Scherer PA, Kneifel H (1983) Distribution of polyamines in methanogenic bacteria. J Bacteriol 154:1315-1322

Schleifer KH (1985) Analysis of the chemical composition and primary structure of murein. Methods Microbiol 18:123-156

Schumann P (2011) Peptidoglycan structure. Methods Microbiol 38:101-129

Schwyn B, Neilands JB (1987) Universal chemical assay for the detection and determination of siderophores. Anal Biochem 160:47-56

Shida O, Takagi H, Kadowaki K, Nakamura LK, Komagata K (1997) Transfer of Bacillus alginolyticus, Bacillus chondroitinus, Bacillus curdlanolyticus, Bacillus glucanolyticus, Bacillus kobensis, and Bacillus thiaminolyticus to the genus Paenibacillus and emended description of the genus Paenibacillus. Int J Syst Bacteriol 47:289-298

Shokri D, Emtiazi G (2010) Indole-3-acetic acid (IAA) production in symbiotic and non-symbiotic nitrogen-fixing bacteria and its optimization by Taguchi design. Curr Microbiol 61:217-225
Skerman VBD (1967) A guide to the identification of the genera of bacteria, 2nd edn. Williams and Wilkins, Baltimore

Staneck JL, Roberts GD (1974) Simplified approach to identification of aerobic actinomycetes by thin-layer chromatography. Appl Microbiol 28:226-231

Taibi G, Schiavo MR, Gueli MC, Calanni Rindina P, Muratore R, Nicotra CMA (2000) Rapid and simultaneous highperformance liquid chromatography assay of polyamines and monoacetylpolyamines in biological specimens. J Chromatogr B 745:431-437

Tamura K, Stecher G, Peterson D, Filipski A, Kumar S (2013) MEGA6: molecular evolutionary genetics analysis version 6.0. Mol Biol Evol 30:2725-2729

Thompson JD, Gibson TJ, Plewniak F, Jeanmougin F, Higgins DG (1997) The CLUSTAL_X windows interface: flexible strategies for multiple sequence alignment aided by quality analysis tools. Nucleic Acids Res 25:4876-4882

Valverde A, Peix A, Rivas R, Velázquez E, Salazar S, SantaRegina I, Rodríguez-Barrueco C, Igual JM (2008) Paenibacillus castaneae sp. nov., isolated from the phyllosphere of Castanea sativa Miller. Int J Syst Evol Microbiol 58:2560-2564

Vaz-Moreira I, Faria C, Nobre MF, Schumann P, Nunes OC, Manaia CM (2007) Paenibacillus humicus sp. nov., isolated from poultry litter compost. Int J Syst Evol Microbiol 57:2267-2271

Verma N, Singh NA, Kumar N, Raghu HV (2013) Screening of different media for sporulation of Bacillus megaterium. Int J Micro Res Rev 1(4):068-073

Wang L, Baek SH, Cui Y, Lee HG, Lee ST (2012) Paenibacillus sediminis sp. nov., a xylanolytic bacterium isolated from a tidal flat. Int J Syst Evol Microbiol 62:1284-1288

Weisburg WG, Barns SM, Pelletier DA, Lane DJ (1991) 16S ribosomal DNA amplification for phylogenetic study. J Bacteriol 173:697-703

Weller DM (2007) Pseudomonas biocontrol agents of soilborne pathogens: looking back over 30 years. Phytopathology 97:250-256

Yoon JH, Kang SJ, Yeo SH, Oh TK (2005) Paenibacillus alkaliterrae sp. nov., isolated from an alkaline soil in Korea. Int J Syst Evol Microbiol 55:2339-2344 